\title{
Multidisciplinary/interdisciplinary actions in the care of elderly with Alzheimer's Disease
}

\author{
Ações multidisciplinares/interdisciplinares no cuidado ao idoso com Doença de Alzheimer
}

Thaís Mara Alexandre Bertazone ${ }^{1}$, Mariana Ducatti², Helen Palmira Miranda de Camargo ${ }^{3}$, Jéssica Magalhães Felipe Batista ${ }^{1}$, Luciana Kusumota ${ }^{1}$, Sueli Marques ${ }^{1}$

Objective: to identify the available evidence in the literature on the effect of multidisciplinary/interdisciplinary actions on health or in the treatment of the elderly with Alzheimer's disease. Methods: an integrative revision made in databases, without accrual period of publication of articles, using controlled and non controlled descriptors. Results: the initial search resulted in a total of 508 studies, six of which were considered eligible for analysis. The results showed that the multidisciplinary/interdisciplinary actions used were effective in the care of the elderly with Alzheimer's disease. The main effects observed were improved behavioral problems and cognitive function and the decrease use of psychotropic drugs. Conclusion: multidisciplinary/interdisciplinary actions can provide more effective care for the elderly with Alzheimer's disease, maximizing their cognitive and functional levels, with improvement in the quality of life for both the patient and for the family/caregivers.

Descriptors: Aged; Alzheimer Disease; Interdisciplinary Research; Patient Care Team.

Objetivo: identificar as evidências disponíveis na literatura sobre o efeito das ações multidisciplinares/ interdisciplinares na saúde ou no tratamento do idoso com Doença de Alzheimer. Métodos: revisão integrativa realizada em bases de dados, sem delimitação de período de publicação dos artigos, utilizando-se descritores controlados e não controlados. Resultados: a busca inicial resultou em um total de 508 estudos, dos quais seis foram considerados elegíveis para análise. Os resultados mostraram que as ações multidisciplinares/ interdisciplinares utilizadas foram efetivas no cuidado ao idoso com Doença de Alzheimer. Os principais efeitos observados foram a melhoria dos problemas comportamentais e da função cognitiva e a diminuição do uso de drogas psicotrópicas. Conclusão: as ações multidisciplinares/interdisciplinares podem oferecer cuidados mais efetivos para os idosos com Doença de Alzheimer, maximizando seu nível cognitivo e funcional, com melhoria da qualidade de vida tanto para o paciente, quanto para os familiares/cuidadores.

Descritores: Idoso; Doença de Alzheimer; Pesquisa Interdisciplinar; Equipe de Assistência ao Paciente.

\footnotetext{
${ }^{1}$ Escola de Enfermagem de Ribeirão Preto, Universidade de São Paulo. Ribeirão Preto, SP, Brazil

${ }^{2}$ Faculdade de Filosofia, Ciências e Letras de Ribeirão Preto, Universidade de São Paulo. Ribeirão Preto, SP, Brazil.

${ }^{3}$ Faculdade de Ciências Farmacêuticas de Ribeirão Preto, Universidade de São Paulo. Ribeirão Preto, SP, Brazil.

Corresponding author: Sueli Marques

Av. dos Bandeirantes, 3900. Campus Universitário - Bairro Monte Alegre, CEP: 14040-902. Ribeirão Preto, SP, Brazil. E-mail: smarques@ eerp.usp.br
} 


\section{Introduction}

The growth of the elderly population is a worldwide phenomenon. In Brazil it is occurring at an accelerated rate due to lower fertility, mortality rates and increased life expectancy ${ }^{(1)}$. This phenomenon, in turn, brings changes in the patterns of morbidity and mortality of the population. Among the main noncommunicable diseases in the elderly population, an increase in the prevalence of dementia has been noticed $^{(2)}$, being Alzheimer's disease the main one.

Alzheimer's disease is characterized by failures in memory, learning and language, which tend to worsen with the progression of the disease. The diagnosis is considered probable when there is evidence of genetic damage and possible when there is no such evidence, but the loss of cognitive functions occurs gradually and there is no other etiology. There are four criteria of diagnosis for the definition of the disease: the presence of neural cognitive disorders syndrome; the slow but gradual emergence of failures in cognitive functions; the classification possible or probable; and the absence of neurodegenerative or cerebral vascular disease and the absence of some kind of disorder whether neurological, mental or systemic $^{(3)}$. There is no cure for it, but pharmacological treatments and the neural cognitive rehabilitation delay and / or temporarily stagnate the progression of the disease $\mathrm{e}^{(4-6)}$.

The total number of people with dementia worldwide in 2010 was estimated at 35.6 million and it is projected to nearly double every 20 years to 65.7 million in 2030 and 115.4 million in $2050^{(2)}$. In the United States, the estimate was 4.5 million in 2000 and the forecast for 2050 is 13.2 million $^{(7)}$. In Brazil, the projections indicate that the average prevalence is higher than the world, as in the population aged 65 and over, this figure will increase from $7.6 \%$ to $7.9 \%$ between 2010 and 2020, with 55,000 new cases a year $^{(8)}$.

Because it is a neurodegenerative and disabling disease, Alzheimer's disease carries high costs related to healthcare. The total cost estimated worldwide was 604 billion dollars in $2010^{(2,9)}$, and the countries that spend more in the care of dementia are the United States, China and Japan ${ }^{(10)}$. In Brazil, the researches on the costs related to the disease are still incipient, with emphasis on epidemiological studies ${ }^{(11-13)}$.

The elderly with Alzheimer's disease have their physical, mental and social integrity jeopardized, which entails situations of total or partial dependence, often requiring complex care. Because it is a disease that affects various aspects of life of the elderly/ family, it is needed to have integrated interventions from different health care professionals through multidisciplinary/interdisciplinary actions ${ }^{(14)}$.

In addition, behavioral and psychological symptoms of dementia, commonly present in the elderly with Alzheimer's disease, jeopardize both the health of the patient as well as the health of family members/ caregivers involved ${ }^{(15-16)}$. A psychotherapeutic intervention is many times appointed to the family members/caregivers of the elderly with Alzheimer's disease, by the fact that almost half of them show signs of stress or depression, and tend to describe their health more negatively when compared to people who do not exercise the role of care ${ }^{(17)}$.

When speaking in multidisciplinary/interdisciplinary actions, there is relevance in the definition of some concepts. A multidisciplinary approach is the set of disciplines that simultaneously deal with a given question without having the health professionals establishing effective relations with each other in the technical or scientific field ${ }^{(18)}$. The interdisciplinary part of the integration of the assumption among disciplines and the intensity of exchanges among professionals by incorporating their expertise in a new way of acting and in the way how health care is provided, avoiding the perspective of individuality and consequently the fragmentation of care ${ }^{(19-20)}$.

The multidisciplinary/interdisciplinary actions are aimed at achieving impacts on the different factors interfering in the health-disease process, through a complete approach to the subject and 
family members by intervening with actions turned to the reality in which they are inserted ${ }^{(21)}$. Thus, this integrative review is justified by the lack of evidence in the literature related to the multidisciplinary/ interdisciplinary actions of health in the care of elderly with Alzheimer's disease, so the aim of this review was to identify the available evidence in the literature on the effect of Multidisciplinary/interdisciplinary actions on the health or on the treatment of the elderly with Alzheimer's disease.

\section{Methods}

Six steps were taken for this integrative revision: issue identification and selection of the hypothesis or question of research; establishment of criteria for inclusion and exclusion of studies/ sampling or search in the literature; definition of the information to be extracted from selected studies/ categorization of studies; assessment of studies included in the integrative revision; interpretation of results and presentation of the revision/synthesis of knowledge ${ }^{(22)}$.

The guiding question for the preparation of the revision was: "What is the effect of multidisciplinary/ interdisciplinary actions on health or on the treatment of the elderly with Alzheimer's disease?"

The pursuit of the studies included in this revision took place in October 2014 in Ribeirão Preto, São Paulo, Brazil, with the use of two electronic databases: US National Library of Medicine, National Institutes of Health (PubMed) and Caribbean and Latin American literature in Health Sciences (LILACS).

For the research in the databases both the controlled descriptors - Medical Subject Headings (MeSH) and the Descriptors in Health Sciences (DeCS) - as well as the non controlled descriptors were used. In the PubMed, the controlled descriptors (provided by $\mathrm{MeSH}$ ) used were: aged, Alzheimer Disease, Interdisciplinary Studies, and Patient Care Team. And the non controlled descriptors were: Interdisciplinary Program, Interdisciplinary Research and Multidisciplinary team. In LILACS, the controlled descriptors (provided by DeCS) used were: aged, Alzheimer's disease, interdisciplinary Research and Patient Care Team. And the non controlled descriptors were: Interdisciplinary Program and Multidisciplinary team and Interdisciplinary Program and Multidisciplinary Team. In all crossings the Boolean operators "AND", "OR" and "AND NOT" were used.

The inclusion criteria were the original articles that addressed the elderly subject with Alzheimer's disease related to multidisciplinary/interdisciplinary teams and assistance teams to the patient, published in English, Portuguese and Spanish. The period of publication of articles, aiming at expanding the search was not delimited. The criteria of exclusion were the publications that did not fit in the classification of the level of used evidence, studies made in animals, editorials, letters to the editor, dissertations, theses, literature revisions, and articles without summaries that did not have available text.

For the classification of the level of evidence, the system of hierarchy of evidence which establish seven levels was used: Level I (Evidence obtained from systematic revision or meta-analysis of all relevant randomized clinical controlled trials or guidelines based on integrative revisions of randomized clinical trials or clinical guidelines based on systematic revisions of Controlled Randomized Clinical Trial); Level II (Evidence obtained from at least one well designed randomized clinical trial); Level III (Evidence obtained from well designed randomized clinical trials); Level IV (evidence from studies of case-control and cohort studies); level V (Evidence obtained from integrative revisions of descriptive and qualitative studies); level VI (evidence obtained from a single descriptive or qualitative study) and level VII (evidence obtained from the opinion of the authorities and/or from the committee of specialists) ${ }^{(23)}$.

The organization of the data obtained from the articles analyzed was performed using a validated instrument that addresses the identification of 
the article, the authors, the type of publication, methodological detail, the sample detail, the studied intervention, the results, and recommendations/ conclusions $^{(24)}$. The selected publications were classified according to the methodological design and the level of evidence and the summary of results is presented descriptively.

All ethical aspects related to the preparation and development of an integrative revision was followed, and the articles which were used were public, and therefore there was no need to ask for their use. The analysis of the studies was faithful to the original texts.

\section{Results}

All the articles were analyzed first by reading the titles and selected based on the objective and guiding question of this revision. The abstracts were read, and among the selected studies after this process, the full articles were read, and from those, the eligible studies for analysis were chosen. The initial search resulted in a total of 508 studies, of which 395 were selected after the exclusion of the repeated ones. Then, 125 studies were selected, and of these, 94 were excluded. Thus, 31 full articles were assessed for eligibility, of these, 25 were excluded, 23 did not fit the inclusion criteria and two for being in other languages. Thus, six articles were eligible for analysis after thorough reading of the article, being all the articles analyzed available on PubMed database.

The selected articles were published between 1998 and 2011. Of the six analyzed publications, three were European, two American and one Brazilian. The methodological characteristics of the studies concerning the objectives, design and members of multidisciplinary/interdisciplinary teams are described in figure 1.

Study 1 analyzed 41 elderly patients with Alzheimer's disease, and both the experimental group and the control group were evaluated using scales that measured the degree of cognitive impairment and quality of life of the participants before and after the intervention, and also the psychological counseling with the caregivers was provided. The results of inventories to assess cognitive impairment and quality of life have shown that the elderly in the experimental group maintained their level of cognitive impairment, whereas the elderly of the control group showed a decline in cognition. Caregivers, in turn, reported improvement in quality of life.

In study 2, 153 elderly people with Alzheimer's disease were analyzed, and the elderly in the intervention group and their caregivers received a year of care management by an interdisciplinary team. Collaborative care for the treatment of the disease resulted in significant improvement in the quality of care, and in the behavioral and psychological symptoms of dementia among the elderly in primary care. This improvement was followed by a reduction in stress of caregivers and was achieved without significantly increasing the use of antipsychotics or hypnotics sedative drugs.

In study 3 , the actions promoted by the team were directed to the elderly and family members/ caregivers, focusing on evaluations of the drug therapy, educational interventions with information on Alzheimer's Disease, advice to caregivers on how to communicate with the elderly, as well as guidelines about legal and financial issues that permeate the situation of care. According to the needs presented, interventions related to the presence of signs/ symptoms of depression/anxiety, aggression/ agitation, repetitive behavior and delusions/ hallucinations/paranoia, sleep disorders were also implemented, as well as for managing personal care and mobility. The study did not show measurable results, but showed that interventions were well received by the elderly/caregivers/family members as well as by doctors of primary health care.

In study 4, the intervention was based on home visits by psychologists and occupational therapists, who provided guidelines on dementia, in addition to management for behavioral problems. The results 
showed that the amount of time spent for the care and high frequency of behavior problems were significantly correlated to the presence of stress in caregivers. The determining factor for the institutionalization of the elderly was the high level of stress of caregivers. The intervention was effective in reducing the frequency of the behavior problems, particularly concerning the agitation and hallucinations. To a lesser extent, a decrease in the time of care was observed.
The multidisciplinary interventions implemented in the sample of participants of study 05 were aimed at complementing the pharmacological treatment. The interventions consisted in the use of techniques of orientation of reality, external support, mnemonic resources, facilitating learning, reminiscence therapy and environmental adaptation. The study also promoted interventions directed to the family members/caregivers, addressing specific questions about

\begin{tabular}{|c|c|c|c|}
\hline Study & Objective & Design (type of study) & $\begin{array}{l}\text { Members of multidisciplinary/interdis- } \\
\text { ciplinary teams }\end{array}$ \\
\hline 1 & $\begin{array}{l}\text { To evaluate the effects of a multidisciplinary } \\
\text { rehabilitation program on cognition, quality of life, } \\
\text { and neuropsychiatric symptoms in patients with mild } \\
\text { Alzheimer's disease }^{(25)} \text {. }\end{array}$ & $\begin{array}{l}\text { Blind study (single-blind), } \\
\text { controlled }\end{array}$ & $\begin{array}{l}\text { It does not describe the professionals of the } \\
\text { multidisciplinary team }\end{array}$ \\
\hline 2 & $\begin{array}{l}\text { To test the efficacy of a model of collaborative } \\
\text { assistance to improve the quality of care for patients } \\
\text { with Alzheimer's disease }{ }^{(26)} \text {. }\end{array}$ & Controlled clinical trial & $\begin{array}{l}\text { Psychologist, neuropsychologist, geriatri- } \\
\text { cian, geriatric psychiatrist and nurse }\end{array}$ \\
\hline 3 & $\begin{array}{l}\text { To describe non-pharmacological protocols for } \\
\text { the treatment of patients with Alzheimer's disease } \\
\text { and their family members, who are part of a care } \\
\text { management program in a primary care clinic }{ }^{(27)} \text {. }\end{array}$ & $\begin{array}{l}\text { Study of randomized } \\
\text { intervention }\end{array}$ & Nurse, doctor, social psychologist \\
\hline 4 & $\begin{array}{l}\text { To evaluate the effect of a structured intervention } \\
\text { in relation to the stress of caregivers and } \\
\text { institutionalization rates of patients with dementia } \\
\text { and behavioral disorders }{ }^{(28)} \text {. }\end{array}$ & $\begin{array}{l}\text { Study of randomized } \\
\text { intervention (pilot study) }\end{array}$ & Occupational therapists and psychologists \\
\hline 5 & $\begin{array}{l}\text { To present preliminary results of the 'combined } \\
\text { treatment' (anticholinesterase drug }+ \text { cognitive } \\
\text { training) in a group of patients with mild Alzheimer's } \\
\text { disease, assisted for seven months }{ }^{(29)} \text {. }\end{array}$ & Clinical trial & $\begin{array}{l}\text { Psychiatrists, psychologists and speech } \\
\text { therapists }\end{array}$ \\
\hline 6 & $\begin{array}{l}\text { To assess the effectiveness of care provided to a group } \\
\text { of special units of care to patients with moderate to } \\
\text { severe dementia affected by behavioral disorders }{ }^{(30)} \text {. }\end{array}$ & $\begin{array}{l}\text { Study of intervention with } \\
\text { no control group }\end{array}$ & Nurse, doctor and therapist \\
\hline
\end{tabular}

Figure 1 - Methodological characteristics of the study 
the etiology and progression of Alzheimer's disease, as well as techniques to provide greater independence to the elderly. The results showed a tendency to improvement in cognitive and functional aspects of older people and reduction of the psychiatric symptoms evaluated, but statistically not significant. Regarding the assistance provided to family members/caregivers of the elderly, there was a reduction in the existing level of psychiatric symptoms significantly altering the welfare of the elderly and their family members.

Study 6 provided adaptations in the premises of institutions specialized in the care of people with dementia, as well as specific training to the teams of nursing and doctors who were caregivers. Aspects related to cognition, function, behavior, general health and use of drug therapy were evaluated. The implemented strategy was effective because it was found that the behavioral problems improved and the use of psychotropic drugs decreased. The reduction of symptoms was gradual and significant for anxiety, agitation and motor performance.

\section{Discussion}

Studies related to the effect of multidisciplinary/ interdisciplinary actions on health or on the treatment of the elderly with Alzheimer's disease are scarce in Brazilian and foreign literature, moreover, existing studies, most of the time, do not detail precisely the professionals involved in treating these elderly, making it difficult to compare the studies analyzed, and often also do not specify whether the treatment was a multidisciplinary/interdisciplinary action, and describe only that it was a team effort.

It was observed that in studies 1, 2, 3 and 5, interventions implemented were directed both for the elderly with Alzheimer's disease and for their family members/caregivers, since improving the quality of life is not centered only on the patient but also on family members/caregivers, because they offer help and support for the coping of daily difficulties related to the disease. In study 4 , the stress of family members/caregivers of patients with Alzheimer's disease was evaluated, and study 06 focused on the assistance to the elderly with Alzheimer's disease.

The caregiver, whether he was a family member or not, appears as an indispensable element in the monitoring process of the elderly with Alzheimer's disease, because he is the one who calls the responsibility of carrying out the tasks for which the elderly no longer has the possibility to carry out ${ }^{(31)}$. This process of care can cause emotional impact, overload and stress for caregivers ${ }^{(17,32)}$.

Behavioral and psychological symptoms arising from the process of dementia, commonly present in the elderly with Alzheimer's disease, affect both patient health and the health of family members/ caregivers $\left({ }^{15,17}\right)$. However, the results of study 2 showed that there might be improvement in the behavioral and psychological symptoms of dementia among primary care patients when treatment is performed by a multidisciplinary/interdisciplinary health team. Data that corroborate those of a study of qualitative analysis made with health professionals of an interdisciplinary team, in which, the professionals state that only with a collaborative discussion the objectives set by the team members themselves to coordinate and make joint decisions about patient care was achieved, allowing to solve problems collaboratively ${ }^{(33)}$.

According to study 04, the stress of family members/caregivers is often related to the amount of time spent in the care of the elderly with Alzheimer's disease and the high frequency of behavioral problems. However, study 2 also showed that collaborative care for treatment of the disease when provided by an interdisciplinary team show significant improvement in the stress of caregivers. A recent study which goes along with this one, highlighted the replication of evidence based on a program to reduce the disability resulting from the Alzheimer's Disease, and explored the changes in outcomes for family members/caregivers who participated in the study and these changes were related to the use of the 
program. The results showed that a multidisciplinary action program may have positive benefits for family members/caregivers ${ }^{(34)}$.

Some studies related to educational interventions structured to help family members/caregivers deal with the behavioral problems of the elderly with Alzheimer's disease have shown that when these actions are performed, there is an improvement of quality of life, a decrease in the stress and in the rates of institutionalization of the elderly with this disea-

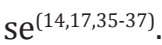

Although there is no cure for Alzheimer's disease, study 1 showed that the intervention was effective to stabilize the cognitive impairment of elderly people with the disease and also improve the quality of life of caregivers. In this perspective, the importance of working with the elderly with Alzheimer's disease and their family members/ caregivers was observed, using techniques such as, cognitive stimulation for patients with cognitive impairment, and psycho education (clarification of dementia) for caregivers ${ }^{(38)}$. Furthermore, it is necessary to emphasize the importance of pharmacological and non-pharmacological standards for the treatment of Alzheimer's disease ${ }^{(5)}$. Thus, the multidisciplinary/interdisciplinary actions with the patients and their caregivers, collaborate for the stagnation of cognitive decline and improve quality of life, respectively.

Studies show that the multidisciplinary team can offer potentially more effective and efficient care for dementia because the elderly with Alzheimer's disease experience a range of symptoms that can overload the family members/caregivers, being necessary to seek measures of care which associate the reduction of costs with health care to a maximum efficacy possible. The presence of a multidisciplinary team can provide effective care for the elderly with Alzheimer's disease, as it reduces access to various services or ineffective therapies. Treatments and research that seek to identify improvement strategies for people with dementia, including Alzheimer's disease, need to be individualized and multidisciplinary, considering the symptoms and specific characteristics of each patient, such as changes in memory, difficulty with daily life activities or speech deficits ${ }^{(4,39-41)}$.

However, the importance of studies related to multidisciplinary/interdisciplinary actions for the elderly with Alzheimer's disease and their family members/caregivers is observed, since they are primarily responsible for the quality of life of the elderly. Some objectives of the orientation to the family are related to dealing with the emotional and work overload generated by continued care.

\section{Conclusion}

Evidence showed that when treatment for elderly people with Alzheimer's disease is carried out by multidisciplinary/interdisciplinary teams, proves to be effective to control the cognitive decline of the elderly and to improve their quality of life, and the quality of life of their family members/caregivers.

It was also found that when testing the effectiveness of collaborative care models for the elderly with Alzheimer's disease, the results showed significant improvement in the quality of care and behavioral and psychological symptoms of dementia among the elderly under primary care, thus reducing the level of stress of caregivers. It was also observed that the association of cognitive rehabilitation techniques to drug treatment can help stabilize the symptoms of Alzheimer's disease or even result in a slight improvement of cognitive and functional deficits, which are progressive characteristics in the course of this disease.

However, because the care management programs for the elderly with Alzheimer's disease are innovative, there was the need to train professionals involved in accordance with treatment protocols, and for best results, the importance of making new studies was emphasized with more samples and control groups for comparison.

It was also observed that studies which 
are concerned in developing multidisciplinary/ interdisciplinary actions aimed at the elderly with Alzheimer's disease are scarce. In this sense, the need for research focusing on multidisciplinary/ interdisciplinary actions for the elderly with Alzheimer's disease is noticed, aiming at the gradual improvement of the care rendered, given the severity of the disease, and its increase in the elderly population and its consequences for family members/caregivers.

For the current scenario, as there is still no cure for Alzheimer's disease, there is the need for services of assistance to the caregiver and family members with multidisciplinary and interdisciplinary teams integrated, working in order to maintain the elderly independent and help reduce costs with the disease.

Multidisciplinary/interdisciplinary actions can provide more effective care for the elderly with Alzheimer's disease, maximizing their cognitive and functional level, with improved quality of life for both the patient and for the family members/caregivers.

\section{Collaborations}

Bertazone TMA and Ducatti M contributed to the design, search and analysis, writing of the article, relevant critical revision and final approval of the version to be published. Camargo HPM and Batista JMF contributed to designing, search and analysis and writing of the article. Kusumota $\mathrm{L}$ and Marques $\mathrm{S}$ contributed to design and relevant critical review.

\section{References}

1. Closs VE, Schwanke CHA. A evolução do índice de envelhecimento no Brasil, nas suas regiões e unidades federativas no período de 1970 a 2010. Rev Bras Geriatr Gerontol. 2012; 15(3):443-58.

2. World Health Organization. Dementia: a public health priority. Geneva: WHO; 2012.

3. American Psychiatric Association. Manual diagnóstico e estatístico de transtornos mentais. Transtornos Neurocognitivos. $5^{\mathfrak{a}}$ ed. Porto Alegre: Artmed; 2014.
4. Da-Silva SL, Pereira DA, Veloso F, Satler CE, Arantes A, Guimarães RM. Programa de reabilitação neuropsicológica da memória aplicada à demência: um estudo não controlado intrasujeitos. Estud Psicol. 2011; 28(2):229-40.

5. Engelhardt E, Brucki SMT, Cavalcanti JLS, Forlenza OV, Laks J, Vale FAC, et al. Treatment of Alzheimer's Disease: recommendations and suggestions of the Scientific Department of Cognitive Neurology and Aging of the Brazilian Academy of Neurology. Arq Neuropsiquiatr. 2005; 63(4):1104-12.

6. Forlenza OV. Tratamento farmacológico da doença de Alzheimer. Rev Psiquiatr Clín. 2005; 32(3):13748.

7. Hebert LE, Scherr PA, Bienias JL, Bennett DA, Evans DA. Alzheimer disease in the USA population: prevalence estimates using the 2000 census. Arch Neurol. 2003; 60(8):1119-22.

8. Burlá C, Camarano AA, Kanso S, Fernandes D, Nunes R. Panorama prospectivo das demências no Brasil: um enfoque demográfico. Ciênc Saúde Coletiva. 2013; 18(10):2949-56.

9. Wimo A, Jonsson L, Bond J, Prince M, Winblad B, Alzheimer disease international. The worldwide economic impact of dementia 2010. Alzheimers Dement. 2013; 9(1):1-11.

10. Wimo A, Winblad B, Jonsson L. The worldwide societal costs of dementia: Estimates for 2009. Alzheimers Dement. 2010; 6(2):98-103.

11. Lopes MA, Bottino CMC. Prevalência de demência em diversas regiões do mundo: análise dos estudos epidemiológicos de 1994 a 2000. Arq Neuropsiquiatr. 2002; 60(1):61-9.

12. Scazufca M, Menezes PR, Vallada HP, Crepaldi AL, Pastor-Valero M, Coutinho LM, et al. High prevalence of dementia among older adults from poor socioeconomic backgrounds in São Paulo, Brazil. Int Psychogeriatr. 2008; 20(2):394-405.

13. Veras P, Caldas CP, Dantas SB, Sancho LG, Sicsú B, Motta LB. Demented elderly people living at home in Rio de Janeiro, Brazil: evaluation of expenditure care. Psychogeriatrics. 2008; 8(2):88-95.

14. Luzardo AR, Gorini MIPC, Silva APSS. Características de idosos com doença de Alzheimer e seus cuidadores: uma série de casos em um serviço de neurogeriatria. Texto Contexto Enferm. 2006; 15(4):587-94. 
15. Haupt M, Kurz A, Janner M. A 2-year follow-up of behavioural and psychological symptoms in Alzheimer's disease. Dement Geriatr Cogn Disord. 2000; 11(3):147-52.

16. Seima MD, Lenardt, MH. A sobrecarga do cuidador familiar de idoso com Alzheimer. Textos Contextos. 2011; 10(2):338-98.

17. Inouye K, Pedrazzani ES, Pavarini SCI. Implicações da doença de Alzheimer na qualidade de vida do cuidador: um estudo comparativo. Cad Saúde Pública. 2010; 26(5):891-9.

18. Almeida Filho N. Transdisciplinaridade e Saúde Coletiva. Ciênc Saúde Coletiva. 1997; 2(1/2):5-23.

19. Costa RP. Interdisciplinaridade e equipes de saúde: concepções. Mental. 2007; 5(8):107-124.

20. Cutolo LRA, Madeira KH. O trabalho em equipe na estratégia Saúde da Família: uma análise documental. Arq Catarin Med. 2010; 39(3):79-84.

21. Araújo MBS, Rocha PM. Trabalho em equipe: um desafio para a consolidação da estratégia de saúde da família. Ciênc Saúde Coletiva. 2007; 12(2):45564.

22. Mendes KDS, Silveira RCCP, Galvão CM. Revisão Integrativa: método de pesquisa para a incorporação de evidências na saúde e na enfermagem. Texto Contexto Enferm. 2008; 17(4):758-64.

23. Melnyk BM, Fineout-Overholt E. Making the case for evidence-based practice. Evidence-based practice in nursing \& healthcare. A guide to best practice. Philadelphia: Lippincot Williams \& Wilkins; 2011.

24. Ursi ES, Galvão CM. Perioperative prevention of skin injury: an integrative literature review. Rev Latino-Am Enfermagem. 2006; 14(1):124-33.

25. Viola LF, Nunes PV, Yassuda MS, Aprahamian I, Santos FS, Santos GD, et al. Effects of a multidisciplinar cognitive rehabilitation program for patients with mild Alzheimer's Disease. Clinics. 2011; 66(8):1395-400.

26. Callahan CM, Boustani MA, Unverzagt FW, Austrom MG, Damush TM, Perkins AJ, et al. Effectiveness of collaborative care for older adults with Alzheimer Disease in Primary Care: a randomized controlled trial. JAMA. 2006; 295(18):2148-57.
27. Austrom MG, Damush TM, Hartwell CW, Perkins T, Unverzagt F, Boustani M, et al. Development and implementation of nonpharmacologic protocols for the management of patients with Alzheimer's Disease and their families in a multiracial primary care setting. Gerontologist. 2004; 44(4):548-53.

28. Nobili A, Riva E, Tettamanti M, Lucca U, Liscio $M$, Petrucci B, et al. The effect of a structured intervention on caregivers of patients with dementia and problem behaviors: a randomized controlled pilot study. Alzheimer Dis Assoc Disord. 2004; 18(2):75-82.

29. Bottino CMC, Carvalho IAM, Alvarez AMMA, Avila R, Zukauskas PR, Bustamante SEZ, et al. Reabilitação cognitiva em pacientes com Doença de Alzheimer: Relato de trabalho em equipe multidisciplinar. Arq Neuropsiquiatr. 2002; 60(1):70-9.

30. Bellelli G, Frisoni GB, Bianchetti A, Boffelli S, Guerrini GB, Scotuzzi AM, et al. Special care units for demented patients: a multicenter study. Gerontologist. 1998; 38(4):456-62.

31. Karsch UM. Idosos dependentes: famílias e cuidadores. Cad Saúde Pública. 2003; 19(3):8616.

32. Lemos ND, Gazzola JM, Ramos LR. Cuidando do paciente com Alzheimer: o impacto da doença no cuidador. Saúde Soc. 2006; 15(3):170-9.

33. Bokhour BG. Communication in interdisciplinary team meetings: What are we talking about? J Interprof Care. 2006; 20(4):349-63.

34. Menne HL, Bass DM, Johnson JD, Primetica B, Kearney KR, Bollin S, et al. Statewide implementation of "reducing disability in Alzheimer's disease": impact on family caregiver outcomes. J Gerontol Soc Work. 2014; 57(67):626-39.

35. Livingston G, Barber J, Rapaport P, Knapp M, Griffin M, King D, et al. Clinical effectiveness of a manual based coping strategy programme (START, STrAtegies for RelaTives) in promoting the mental health of carers of family members with dementia: pragmatic randomised controlled trial. BMJ. 2013; 347:6276.

36. Brodaty H, Donkin M. Family caregivers of people with dementia. Dialogues Clin Neurosci. 2009; 11(2):217-28. 
37. Mohide EA, Pringle DM, Streiner DL, Gilbert JR, Muir G, Tew M. A randomized trial of family caregiver support in the home management of dementia. J Am Geriatr Soc. 1990; 38(4):446-54.

38. Camara VD, Gomes S, Ramos F, Moura S, Duarte $\mathrm{R}$, Costa AS, et al. Reabilitação Cognitiva das Demências. Rev Bras Neurol. 2009; 45(1):25-39.

39. Beck KC, Cody M, Zhang M. A multidisciplinary team approach to managing Alzheimer's disease. Pharmacotherapy. 1998; 18(2Pt2):33-42.
40. Cunha FCM, Cunha LCM, Silva HM, Couto EAB. Abordagem funcional e centrada no cliente na reabilitação de idoso com demência de Alzheimer avançada - relato de caso. Rev Ter Ocup. 2011; 22(2):145-152.

41. Brandão L, Parente MAMP. Doença de Alzheimer e a aplicação de diferentes tarefas discursivas. Psicol Reflex Crit. 2011; 24(1):161-9. 